\title{
Pemahaman Pancasila Sebagai Wujud Kepribadian Tangguh Studi Kasus di Bima
}

\author{
Ahmadin \\ STKIP Taman Siswa Bima \\ madin_uni15@yahoo.co.id
}

\begin{tabular}{|c|c|}
\hline Artikel Info & Abstrak \\
\hline$\underline{\text { Tanggal Publikasi }}$ & Hasil analisis menunjukkan bahwa di era teknologi informasi dan komunikasi yang \\
\hline $2019-12-30$ & $\begin{array}{l}\text { berkembang sangat pesat, banyak generasi muda yang bertindak tidak sesuai dengan } \\
\text { nilai-nilai pancasila karena rendahnya kesadaran yang ada pada diri mereka. } \\
\text { Sehingga generasi muda perlu adanya pemahaman pancasila. Karena generasi }\end{array}$ \\
\hline$\underline{\text { Kata Kunci }}$ & sekarang terjerumus dalam lingkaran zaman globalisasi sehingga diharapkan mampu \\
\hline Pemahaman & $\begin{array}{l}\text { menjadi penerus bangsa yang mampu menanamkan serta menerapkan nila1-nila1 } \\
\text { pancasila. Hal yang mendukung tercapainya harapan tersebut adalah dengan adanya }\end{array}$ \\
\hline & pemhaman pancasila yang memberikan pengembangan serta pengetahuan untuk \\
\hline Kepribadian Tangguh & $\begin{array}{l}\text { generasi muda supaya memiliki karakter yang unggul serta mempunyai akhlak yang } \\
\text { baik. Selain itu dengan adanya pendidikan pancasila mampu menumbuhkan } \\
\text { kesadaran pada pribadi generasi dalam berpegang teguh pada kebudayaan yang } \\
\text { sesuai dengan kaidah pancasila. Sehingga generasi muda sekarang mampu membawa } \\
\text { perubahan bagi bangsa Indonesia menuju kearah yang lebih baik. }\end{array}$ \\
\hline
\end{tabular}

\section{PENDAHULUAN}

Ungkapan sejarah bahwa Pancasila tidak terlahir dengan seketika pada tahun 1945, tetapi membutuhkan proses penemuan yang lama, dengan dilandasi oleh perjuangan bangsa dan berasal dari gagasan dan kepribadian bangsa Indonesia sendiri. Proses konseptualisasi yang panjang ini ditandai dengan berdirinya organisasi pergerakan kebangkitan nasional, partai politik, dan sumpah pemuda. Dalam usaha merumuskan Pancasila, muncul usulan pribadi yang dikemukakan dalam sidang Badan Penyelidik Usaha Persiapan Kemerdekaan Indonesia (BPUPKI) antara lain; 1). Mrs. Muhammad Yamin, pada tanggal 29 Mei 1945 berpidato mengemukakan usulannya tentang lima dasar sebagai berikut: Peri Kebangsaan, Peri Kemanusiaan, Peri Ketuhanan, Peri Kerakyatan, dan Kesejahteraan Rakyat. Dia berpendapat bahwa ke-5 sila yang diutarakan tersebut berasal dari sejarah, agama, peradaban, dan hidup ketatanegaraan yang tumbuh dan berkembang sejak lama di Indonesia. Mohammad Hatta dalam memoarnya meragukan pidato Yamin tersebut. (2) Soekarno pada tanggal 1 Juni 1945 mengemukakan Pancasila sebagai dasar negara dalam pidato spontannya yang selanjutnya dikenal dengan judul "Lahirnya Pancasila". Ir. Soekarno merumuskan dasar negara: Kebangsaan Indonesia, Internasionalisme, atau peri-kemanusiaan, Mufakat atau demokrasi, Kesejahteraan sosial, Ketuhanan yang maha esa.

Dari banyak usulan yang mengemuka, Ir. Soekarno berhasil mensintesiskan dasar falsafah dari banyak gagasan dan pendapat yang disebut Pancasila pada 1 Juni 1945. Rumusan dasar Negara ini kemudian dikembalikan oleh panitia yang dibentuk BPUPKI (Badan Penyelidik Usaha Persiapan Kemerdekaan Indonesia) dan dimasukkan ke Piagam Jakarta. Selanjutnya pada tanggal 18 Agustus 1945 Pancasila secara sah menjadi dasar Negara yang mengikat. Sebelum disahkan, terdapat bagian yang di ubah" Ke-Tuhanan, dengan kewajiban menjalankan syariat Islam bagi pemeluk-pemeluknya" diubah menjadi Ketuhanan Yang Maha Esa”. Rumusan butir-butir Pancasila yang pernah digagas, baik yang disampaikan dalam pidato Ir. Soekarno ataupun rumusan Panitia Sembilan yang termuat dalam Piagam Jakarta adalah sejarah dalam proses penyusunan dasar negara. Rumusan tersebut semuanya otentik sampai akhirnya disepakati rumusan sebagaimana terdapat pada alinea keempat Pembukaan 
Undang-Undang Dasar 1945 yang disahkan pada tanggal 18 Agustus 1945. Berdasarkan sejarah, ada tiga rumusan dasar negara yang dinamakan Pancasila, yaitu rumusan konsep Ir. Soekarno yang dibacakan pada pidato tanggal 1 Juni 1945 dalam sidang BPUPKI, rumusan oleh Panitia Sembilan dalam Piagam Jakarta tanggal 22 Juni 1945, dan rumusan pada Pembukaan Undang-Undang Dasar 1945 yang disahkan oleh PPKI tanggal 18 Agustus 1945. Dengan demikian, rangkaian dokumen sejarah yang bermula dari 1 Juni 1945, 22 Juni 1945, hingga teks final 18 Agustus 1945 itu, dapat dimaknai sebagai satu kesatuan dalam proses kelahiran falsafah negara Pancasila.

\section{Pengertian Pancasila}

Pancasila merupakan ideologi dasar bagi negara Indonesia yang berasal dari ajaran budha dalam kitab tripitaka dua kata: panca yang berarti lima dan syila yang berarti dasar. Jadi secara leksikal Pancasila bermakna lima aturan tingkah laku yang penting. Pengertian Pancasila menurut Ir. Soekarno, Pancasila adalah jiwa bangsa Indonesia yang turun-temurun sekian lamanya terpendam bisu oleh kebudayaan barat. Dengan demikian, Pancasila tidak hanya falsafah bangsa tetapi lebih luas lagi yakni falsafah bangsa Indonesia. Pancasila merupakan hasil perenungan jiwa yang dalam, yang kemudian dituangkan dalam suatu "sistem" yang tepat. Sedangkan Notonagoro (Ruyadi, 2003:16) menyatakan, Filsafat Pancasila memberi pengetahuan dan pengertian ilmiah yaitu tentang hakekat dari Pancasila. Pancasila sebagai suatu sistem filsafat, memiliki dasar ontologis, dasar epistemologis dan dasar aksiologis tersendiri, yang membedakannya dengan sistem filsafat lain.

Secara ontologis, kajian Pancasila sebagai filsafat dimaksudkan sebagai upaya untuk mengetahui hakekat dasar dari sila-sila Pancasila. Notonagoro (Ganeswara, 2007:7) menyatakan bahwa hakekat dasar ontologis Pancasila adalah manusia, sebab manusia merupakan subjek hukum pokok dari Pancasila. Selanjutnya hakekat manusia itu adalah semua kompleksitas makhluk hidup baik sebagai makhluk individu sekaligus sebagai makhluk sosial. Secara lebih lanjut hal ini bisa dijelaskan, bahwa yang berkeTuhanan Yang Maha Esa, yang berkemanusiaan yang adil dan beradab, yang berpersatuan Indonesia, yang berkerakyatan yang dipimpin oleh hikmah kebijaksanaan dalam permusyawaratan/perwakilan serta yang berkeadilan sosial adalah manusia.

Kajian epistemologis filsafat Pancasila, dimaksudkan sebagai upaya untuk mencari hakekat Pancasila sebagai suatu sistem pengetahuan. Menurut Titus (Kaelan, 2007:15) terdapat tiga persoalan mendasar dalam epistemologi yaitu: (1) tentang sumber pengetahuan manusia; (2) tentang teori kebenaran pengetahuan manusia; dan (3) tentang watak pengetahuan manusia.

Tentang sumber pengetahuan Pancasila, sebagaimana diketahui bahwa Pancasila digali dari nilainilai luhur bangsa Indonesia sendiri serta dirumuskan secara bersama-sama oleh "The Founding Fathers" kita. Jadi bangsa Indonesia merupakan Kausa Materialis-nya Pancasila. Selanjutnya, Pancasila sebagai suatu sistem pengetahuan memiliki susunan yang bersifat formal logis, baik dalam arti susunan silasilanya maupun isi arti dari sila-silanya. Susunan sila-sila Pancasila bersifat hierarkhis piramidal. Selanjutnya, sila-sila Pancasila sebagai suatu sistem filsafat juga memiliki satu kesatuan dasar aksiologinya yaitu nilai-nilai yang terkandung dalam Pancasila pada hakekatnya juga merupakan suatu kesatuan.

\section{Filsafat Pancasila Sebagai Pandangan Hidup Bangsa Indonesia}

Pancasila adalah suatu paham filsafat (philosophical way of thinking) oleh karena itu harus dapat dipertanggungjawabkan secara logis dan dapat diterima oleh akal sehat. Dalam pengertian tersebut, Pancasila disebut juga sebagai way of life, weltanschaung, pegangan hidup, petunjuk hidup, dan sebagainya. Dalam hal ini Pancasila adalah sebagai petunjuk arah kegiatan di segala bidang kehidupan, sehingga seluruh tingkah laku dan perbuatan manusia Indonesia harus dijiwai dan merupakan pancaran dari sila-sila Pancasila yang merupakan satu kesatuan yang utuh yang tidak dapat dipisahkan satu dengan yang lain. Sebagai pandangan hidup yang merupakan penjelmaan falsafah hidup bangsa, 
Pancasila dalam pelaksanaannya sehari-hari tidak boleh bertentangan dengan norma-norma agama, norma-norma kesusilaan, norma sopan santun, serta norma-norma hukum yang berlaku.

\section{Pancasila Sebagai Dasar Negara Republik Indonesia}

Sebagai dasar negara, Pancasila harus dapat dipertanggung jawabkan secara yuridis konstitusional (menurut hukum ketatanegaraan), oleh karena itu setiap orang tidak boleh atau tidak bebas memberikan pengertian/penafsiran manurut pendapatnya sendiri. Pancasila dalam pengertian ini sering disebut pula sebagai dasar falsafah negara (philosofische grondslag) atau ideologi negara (staatsidee). Pancasila yang dikukuhkan dalam sidang I dari BPUPKI pada tanggal 1 Juni 1945 adalah di kandung maksud untuk dijadikan dasar bagi negara Indonesia merdeka. Adapun dasar itu haruslah berupa suatu filsafat yang menyimpulkan kehidupan dan cita-cita bangsa dan negara Indonesa yang merdeka. Di atas dasar itulah akan didirikan gedung Republik Indonesia sebagai perwujudan kemerdekaan politik yang menuju kepada kemerdekaan ekonomi, sosial dan budaya.

Sidang BPUPKI telah menerima secara bulat Pancasila itu sebagai dasar negara Indonesia merdeka. Dalam keputusan sidang PPKI kemudian pada tanggal 18 Agustus 1945 Pancasila tercantum secara resmi dalam Pembukaan UUD RI, Undang-Undang Dasar yang menjadi sumber ketatanegaraan harus mengandung unsur-unsur pokok yang kuat yang menjadi landasan hidup bagi seluruh bangsa dan negara, agar peraturan dasar itu tahan uji sepanjang masa. Peraturan selanjutnya yang disusun untuk mengatasi dan menyalurkan persoalan-persoalan yang timbul sehubungan dengan penyelenggaraan dan perkembangan negara harus didasarkan atas dan berpedoman pada UUD. Peraturan-peraturan yang bersumber pada UUD itu disebut peraturan-peraturan organik yang menjadi pelaksanaan dari UUD.

Oleh karena Pancasila tercantum dalam UUD 1945 dan bahkan menjiwai seluruh isi peraturan dasar tersebut yang berfungsi sebagai dasar negara sebagaimana jelas tercantum dalam alinea IV Pembukaan UUD 1945 tersebut, maka semua peraturan perundang-undangan Republik Indonesia (Ketetapan MPR, Undang-undang, Peraturan Pemerintah sebagai pengganti Undang-undang, Peraturan Pemerintah, Keputusan Presiden dan peraturan-peraturan pelaksanaan lainnya) yang dikeluarkan oleh negara dan pemerintah Republik Indonesia haruslah pula sejiwa dan sejalan dengan Pancasila (dijiwai oleh dasar negara Pancasila). Isi dan tujuan dari peraturan perundang-undangan Republik Indonesia tidak boleh menyimpang dari jiwa Pancasila. Bahkan dalam Ketetapan MPRS No. XX/MPRS/1966 ditegaskan, bahwa Pancasila itu adalah sumber dari segala sumber hukum (sumber hukum formal, undang-undang, kebiasaan, traktaat, jurisprudensi, hakim, ilmu pengetahuan hukum).

Di sinilah tampak titik persamaan dan tujuan antara jalan yang ditempuh oleh masyarakat dan penyusun peraturan-peraturan oleh negara dan pemerintah Indonesia. Adalah suatu hal yang membanggakan bahwa Indonesia berdiri di atas fundamen yang kuat, dasar yang kokoh, yakni Pancasila dasar yang kuat itu bukanlah meniru suatu model yang didatangkan dari luar negeri. Dasar negara kita berakar pada sifat-sifat dan cita-cita hidup bangsa Indonesia, Pancasila adalah penjelmaan dari kepribadian bangsa Indonesia, yang hidup di tanah air kita sejak dahulu hingga sekarang. Pancasila mengandung unsur-unsur yang luhur yang tidak hanya memuaskan bangsa Indonesia sebagai dasar negara, tetapi juga dapat diterima oleh bangsa-bangsa lain sebagai dasar hidupnya. Pancasila bersifat universal dan akan mempengaruhi hidup dan kehidupan banga dan negara kesatuan Republik Indonesia secara kekal dan abadi.

\section{Pancasila Sebagai Jiwa Dan Kepribadian Bangsa Indonesia}

Menurut Dewan Perancang Nasional, yang dimaksudkan dengan kepribadian Indonesia ialah: Keseluruhan ciri-ciri khas bangsa Indonesia, yang membedakan bangsa Indonesia dengan bangsabangsa lainnya. Keseluruhan ciri-ciri khas bangsa Indonesia adalah pencerminan dari garis pertumbuhan dan perkembangan bangsa Indonesia sepanjang masa. Garis pertumbuhan dan 
perkembangan bangsa Indonesia yang ditentukan oleh kehidupan budi bangsa Indonesia dan dipengaruhi oleh tempat, lingkungan dan suasana waktu sepanjang masa. Walaupun bangsa Indonesia sejak dahulu kala bergaul dengan berbagai peradaban kebudayaan bangsa lain (Hindu, Tiongkok, Portugis, Spanyol, Belanda dan lain-lain) namun kepribadian bangsa Indonesia tetap hidup dan berkembang. Mungkin di sana-sini, misalnya di daerah-daerah tertentu atau masyarakat kota kepribadian itu dapat dipengaruhi oleh unsur-unsur asing, namun pada dasarnya bangsa Indonesia tetap hidup dalam kepribadiannya sendiri. Bangsa Indonesia secara jelas dapat dibedakan dari bangsabangsa lain. Apabila kita memperhatikan tiap sila dari Pancasila, maka akan tampak dengan jelas bahwa tiap sila Pancasila itu adalah pencerminan dari bangsa kita.

Demikianlah, maka Pancasila yang kita gali dari bumi Indonsia sendiri merupakan : a). Dasar negara kita, Republik Indonesia, yang merupakan sumber dari segala sumber hukum yang berlaku di negara kita. b).Pandangan hidup bangsa Indonesia yang dapat mempersatukan kita serta memberi petunjuk dalam masyarakat kita yang beraneka ragam sifatnya. c). Jiwa dan kepribadian bangsa Indonesia, karena Pancasila memberikan corak yang khas kepada bangsa Indonesia dan tak dapat dipisahkan dari bangsa Indonesia, serta merupakan ciri khas yang dapat membedakan bangsa Indonesia dari bangsa yang lain. Terdapat kemungkinan bahwa tiap-tiap sila secara terlepas dari yang lain bersifat universal, yang juga dimiliki oleh bangsa-bangsa lain di dunia ini, akan tetapi kelima sila yang merupakan satu kesatuan yang tidak terpisahkan itulah yang menjadi ciri khas bangsa Indonesia. d). Tujuan yang akan dicapai oleh bangsa Indonesia, yakni suatu masyarakat adil dan makmur yang merata material dan spiritual berdasarkan Pancasila di dalam wadah negara kesatuan Republik Indonesia yang merdeka, berdaulat, bersatu dan berkedaulatan rakyat dalam suasana perikehidupan bangsa yang aman, tenteram, tertib dan dinamis serta dalam lingkungan pergaulan dunia yang merdeka, bersahabat, tertib dan damai. e). Perjanjian luhur rakyat Indonesia yang disetujui oleh wakil-wakil rakyat Indonesia menjelang dan sesudah Proklamasi Kemerdekaan yang kita junjung tinggi, bukan sekedar karena ia ditemukan kembali dari kandungan kepribadian dan cita-cita bangsa Indonesia yang terpendam sejak berabad-abad yang lalu, melainkan karena Pancasila itu telah mampu membuktikan kebenarannya setelah diuji oleh sejarah perjuangan bangsa.

Oleh karena itu yang penting adalah bagaimana kita memahami, menghayati dan mengamalkan Pancasila dalam segala segi kehidupan. Tanpa ini maka Pancasila hanya akan merupakan rangkaian kata-kata indah yang tertulis dalam Pembukaan UUD 1945, yang merupakan perumusan yang beku dan mati, serta tidak mempunyai arti bagi kehidupan bangsa kita. Apabila Pancasila tidak menyentuh kehidupan nyata, tidak kita rasakan wujudnya dalam kehidupan sehari-hari, maka lambat laun kehidupannya akan kabur dan kesetiaan kita kepada Pancasila akan luntur. Mungkin Pancasila akan hanya tertinggal dalam buku-buku sejarah Indonesia. Apabila ini terjadi maka segala dosa dan noda akan melekat pada kita yang hidup di masa kini, pada generasi yang telah begitu banyak berkorban untuk menegakkan dan membela Pancasila. Akhirnya perlu juga ditegaskan, bahwa apabila dibicarakan mengenai Pancasila, maka yang kita maksud adalah Pancasila yang dirumuskan dalam Pembukaan UUD 1945, yaitu: Ketuhanan Yang Maha Esa, Kemanusiaan yang adil dan beradab, Persatuan Indonesia, Kerakyatan yang dipimpin oleh hikmat kebijaksanaan dalam permusyawratan / perwakilan, dan Keadilan sosial bagi seluruh rakyat Indonesia.

Rumusan Pancasila yang terdapat dalam Pembukaan UUD 1945 itulah yang kita gunakan, sebab rumusan yang demikian itulah yang ditetapkan oleh wakil-wakil bangsa Indonesia pada tanggal 18 Agustus 1945 dalam sidang Panitia Persiapan Kemerdekaan Indonesia (PPKI). Seperti yang telah ditunjukkan oleh Ketetapan MPR No. XI/MPR/1978, Pancasila itu merupakan satu kesatuan yang bulat dan utuh dari kelima silanya. Dikatakan sebagai kesatuan yang bulat dan utuh, karena masingmasing sila dari Pancasila itu tidak dapat dipahami dan diberi arti secara sendiri-sendiri, terpisah dari keseluruhan sila-sila lainnya. Memahami atau memberi arti setiap sila-sila secara terpisah dari sila-sila lainnya akan mendatangkan pengertian yang keliru tentang Pancasila. 


\section{Ideologi Pancasila}

Secara etimologis, istilah Ideologi berasal dari kata "idea" yang berarti gagasan, konsep, pengertian dasar, cita-cita, pemikiran, dan kata "logos" yang berarti ilmu. Kata "oida” berasal dari bahasa Yunani yang berarti mengetahui, melihat, bentuk. Pengertian ideologi secara umum dapat dikatakan sebagai kumpulan gagasan-gagasan, ide-ide, keyakinan-keyakinan, kepercayaan-kepercayaan yang menyeluruh dan sistematis yang menyangkut dan mengatur tingkah laku sekelompok manusia tertentu dalam berbagai bidang kehidupan.

Idologi menurut Gunawan Setiardjo: Ideologi adalah kumpulan ide atau gagasan atau aqidah 'aqliyyah (akidah yang sampai melalui proses berpikir) yang melahirkan aturan-aturan dalam kehidupan.Pada dasarnya ideologi terbagi dua bagian, yaitu Ideologi Tertutup dan Ideologi Terbuka. Ideologi Tertutup merupakan suatu pemikiran tertutup. Sedangkan Ideologi Terbuka merupakan suatu sistem pemikiran terbuka. Ideologi Terbuka memiliki ciri khas yaitu nilai-nilai dan cita-citanya tidak dipaksakan dari luar, melainkan digali dan diambil dari harta kekayaan rohani, moral dan budaya masyarakat sendiri. Ideologi terbuka diciptakan oleh Negara melainkan digali dan ditemukan dalam masyarakat itu sendiri. Oleh karena itu, Ideologi terbuka merupakan milik semua masyarakat dalam menemukan 'dirinya' dan 'kepribadiannya' dalam Ideologi tersebut.

Pancasila sebagai suatu Ideologi tidak bersifat tertutup dan kaku, tetapi bersifat reformatif, dinamis dan terbuka. Hal ini dimaksudkan bahwa Ideologi pancasila besifat aktual, dinamis, antisipatif dan senantiasa mampu menyesuaikan dengan perkembangan zaman, ilmu pengetahuan dan teknologi (iptek), serta dinamika perkembangan aspirasi masyarakat.Keluwesan dan fleksibelitas serta keterbukaan yang dimiliki oleh ideologi Pancasila menjadikan Pancasila tidak ketinggalan zaman dalam tatanan sosial, namun sifatnya yang terbuka bukan berarti nilai-nilai dasar Pancasila dapat dirubah /diganti dengan nilai dasar yang lain. Sebab jika nialai dasar tersebut dirubah berarti meniadakan Pancasila bahkan membubarkan Negara RI. Yang dimaksud dengan ideologi Pancasila yang bersifat terbuka adalah nilai-nilai dasar dari Pancasila dapat dikembangkan sesuai dengan bangsa Indonesia dan tuntutan perkembangan zaman.

Sebagai suatu ideologi yang bersifat terbuka maka secara struktural Pancasila memiliki tiga dimensi sebagai berikut: 1.) Dimensi idealis. bahwa nilai-nilai dasar ideologis tersebut mengandung idealisme, bukan angan-angan yang memberi hambatan tentang masa depan yang lebih baik melalui perwujudan atau pengalamannya dalam praktek kehidupan bersama mereka sehari-hari dengan berbagai dimensinya, 2). Dimensi Fleksibilitas. Bahwa ideologi tersebut memiliki keluwesan yang memungkinkan Merangsang pengembangan pemikiran-pemikiran baru yang relevan tentang dirinya,tanpa menghilangkan hakikat (jati diri) yang terkandung dalam nilai dasar dan 3). Dimensi realitas. adalah suatu Ideologi harus mampu mencerminkan realitas yang hidup $\&$ berkembang dalam masyarakat. Nilai-nilai dasar yang terkandung dalam ideologi secara reel berakar dan hidup dalam masyarakat/bangsanya, terutama karena nilai-nilai dasar tersebut bersumber dari budaya dan pengalaman sejarahnya. Oleh karena itu, selain memiliki dimensi nilai-nilai ideal dan normative, pancasila juga harus mampu dijabarkan dalam kehidupan bermasyarakat secara nyata, baik dalam kehidupan sehari-hari maupun dalam penyelenggaraan Negara.

Berdasarkan dimensi yang dimiliki oleh pancasila sebagai Ideologi terbuka, maka sifat Ideologi pancasila tidak bersifat "utopis", yaitu hanya merupakan sistem ide-ide belaka yang jauh dari kehidupan sehari-hari secara nyata. Pancasila juga bukan merupakan Ideologi "pragmatis" yang hanya menekankan segi praktisi belaka tanpa adanya aspek idealisme. Ideologi Pancasila yang bersifat terbuka hakikatnya nilai-nilai dasar yang bersifat unviversal dan tetap. Adapun penjabaran dan realisasinya senantiasa dieksplisitkan secara dinamis-reformatif yang senantiasa mampu melakukan perubahan sesuai dengan dinamika aspirasi masyarakat. 


\section{Makna Pengamalan Pancasila}

Pancasila adalah lima dasar atau azas Negara Indonesia. Sebagai dasar Negara, Pancasila mengatur semua tatanan kehidupan bermasyarakat di Indonesia. Pancasila lah yang juga mempersatukan Indonesia dan berhasil mengatasi semua konflik di Indonesia yang pernah terjadi selama ini. Pancasila terdiri dari lima nilai yang sangat bermakna dalam kehidupan. Nilai-nilai yang terkadung tersebut dapat menjadikan kehidupan kita semakin lebih baik. Untuk mewujudkan hal tersebut kita wajib mengamalkan lima nilai itu dalam kehidupan sehari-hari.

Siapapun dapat menjalankan ke lima sila tersebut tanpa pandang bulu, sebab pada Pancasila mengandung sila sila yang menyatakan persatuan. Kita dapat mengamalkannya di lingkungan keluarga, sekolah dan masyarakat. Berikut uraiannya; Sila pertama dari Pancasila adalah Ketuhanan Yang Maha Esa. Contoh pengamalannya adalah kita harus bersikap toleransi kepada setiap umat beragama. Dalam sila ini kita juga harus bisa menghormati, menghargai perbedaan dalam keyakinan dan agama. Dan kita harus mengembankan sikap saling menghormati kebebasan menjalankan ibadah sesuai dengan agama dan kepercayaan masing-masing. Serta tidak mengganggu ketertiban dalam beribadah satu sama lain. Sila kedua yaitu kemanusiaan yang adil dan beradab. Dengan terwujud nya sila kedua ini, maka hak hak manusia akan terjaga seperti HAM (Hak Asasi Manusia). Sila kedua ini menentang segala bentuk peperangan apapun itu. Sila kedua ini juga menuntut keadilan untuk setiap warga negara. Sila ketiga yaitu persatuan Indonesia. Contoh pengamalannya adalah kita mampu menempatkan persatuan, kesatuan serta kepentingan dan keselamatan bangsa dan Negara sebagai kepentingan bersama diatas kepentingan pribadi dan golongan. Dan kita juga harus mengembangkan rasa cinta kepada tanah air dan bangsa. Sila keempat yaitu kerakyatan yang dipimpin oleh khidmat kebijksanaan dalam permusyawaratan perwakilan. Saat bermusyawarah tidak boleh menyela atau mengabaikan pendapat orang lain. Dalam sila ini harus diwujudkannya musyawarah yang baik dan lancar. Oleh sebab itu Indonesia juga menganut musyawarah sebagai penentuan keputusan utama. Sila kelima yaitu keadilan sosial bagi seluruh rakyat Indonesia. Dalam pengamalannya kita harus mengembangkan sikap adil terhadap sesama, menjaga keseimbangan hak dan kewajiban, menghormati hak orang lain dan menghargai hasil karya orang lain yang bermanfaat bagi kemajuan dan kesejahteraan bersama.

\section{Pancasila Sebagai Wujud Kepribadian Tangguh}

Asal muasal kata Pancasila berasal dari bahasa Sanskerta, yakni kata Panca yang berati lima dan sila/syla yang memiliki arti batu, sendi, alas atau sebuah dasar. Maka jika ditarik kesimpulan Pancasila memiliki makna sebuah dasar yang terdiri dari lima unsur. Kelima unsur didalam Pancasila tersebut membentuk satu kesatuan yang saling mengikat dan terkait satu sama lain sehingga menjadikan fungsi Pancasila sebagai suatu dasar negara yang utuh dan sempuna. Yang mencerminkan fungsi pokok Pancasila sebagai dasar negara dan ideologi negara. Kedudukan Pancasila sebagai dasar negara dan pandangan hidup bangsa merupakan cerminan dari budaya masyarakat yang menganut nilai-nilai luhur bahkan sebelum terciptanya Pancasila itu sendiri. Sebab Pancasila lahir dari hasil pemikiran-pemikian serta ide maupun gagasan dari budaya yang dimiliki bangsa Indonesia sejak jaman dahulu. Hal ini merupakan cerminan dari fungsi kebudayaan bagi masyarakat itu sendiri sebagai sebuah pemersatu. Nilai-nilai Pancasila sebagai ideologi terbuka memperlihatkan kepribadian bangsa Indonesia itu sendiri, yakni terbuka terhadap segala perubahan.

\section{Kepribadian Bangsa}

Yang dimaksud dengan kepribadian ialah setiap sifat yang terlihat dalam perilaku seseorang atau sebuah bangsa yang membuatnya berbeda dari seseorang atau bangsa lainnya. Setiap orang memiliki orientasi berbeda dalam menghadapi sebuah kondisi tertentu, sehingga tercipta sebuah pola perilaku yang baku dan konsisten. Dengan begitu hal ini menjadi karakteristik pribadinya. Sedangkan bangsa merupakan sebuah perhimpunan yang terdiri dari masyarakat yang saling memiliki keterkaitan dan saling berhubungan untuk mencapai sebuah harapan yang dijadikan sebagi tujuan bersama di sebuah 
wilayah tertentu. Disebuah kehidupan bermasyarakat tercipta dari kelompok mayoritas dan juga minoritas yang membentuk suatu harmoni kehidupan. Bila ditilik dari sisi sosiologis antropologis, bangsa merupakan sesuatu yang diikat oleh suatu ikatan, dapat berupa ras, suku, sejarah, adat budaya dan juga agama atau sebuah keyakinan, bahasa juga daerah. Dan ikatn tersebut dinamakan ikatan primordial. Kepribadian bangsa merupakan ciri-ciri perilaku maupun karakteristik yang terlihat dalam kehidupan suatu masyarakat dalam sebuah kesatuan nasional.

\section{Pancasila Sebagai Kepribadian Bangsa}

Dewan Perancang Nasional menyatakan bahwa kepribadian Indonesia adalah karakteristik yang dimiliki oleh bangsa Indonesia dan berbeda secara menyeluruh dengan keribadian bangsa-bangsa yang lain. Hal tersebut merupakan refleksi dari perubahan dan perkembangan bangsa Indonesia dari masa ke masa. Perubahan yang dialami bangsa Indonesia dipengaruhi dengan segala hal yang terjadi didalam mayarakat, adat budaya serta lingkungan didalam masyarakat itu sendiri. Nilai-nilai Pancasila sebagai Ideologi Terbuka memiliki peranan penting dalam membentuk kepribadian bangsa Indonesia. Membuat karakteristik bangsa menjadi terbuka terhadap segala perubahan yang terjadi baik didalam maupun diluar negeri. Terbuka dengan kebudayaan maupun warga asing yang masuk ke Indonesia, dengan tidak meninggalkan kebudayaan asli milik bangsa Indonesia sendiri. Terutama dalam hal berdemokrasi, Pancasila sebagai Kepribadian Bangsa sangat penting untuk menyelesaikan masalah dengan jalan musyawarah tanpa adanya kekerasan.

Dari hal tersebut terlihat manfaat musyawarah yang merupakan dasar dalam berpendapat tanpa melakukan pelanggaran hak warga negara. Pancasila sendiri merupakan dasar negara yang berasal dari cerminan kehidupan masyarakatnya jadi merupakan milik bangsa Indonesia seluruhnya dan bukan merupakan milik seseorang maupun golongan tertentu.

\section{Kepribadian Bangsa Indonesia dalam Era Globalisasi}

Globalisasi secara umum merupakan sebuah proses dalam sistem masyarakat secara global yang tidak terpengaruh dengan batas wilayah. Pada hakikatnya sebuah globalisasi menurut Edison A. Jamli dkk (Kewarganegaraan.2005) ialah sebuah mekanisme yang muncul dari sebuah pemikiran yang dibentuk yang lantas diperkenalkan pada bangsa lain, hingga sampai pada sebuah titik dimana hal tersebut lantas disepakati dan dijadikan sebagai dasar untuk melaksanakan sebuah sistem tersebut oleh masyarakat dunia. Dan Kirsna berpendapat di dalam jurnalnya Pengaruh Globalisasi Terhadap Pluralisme Kebudayaan Manusia di Negara Berkembang (internet public jurnal september 2005) bahwa sebagai sebuah mekanisme proses, globalisasi terjadi dengan melalui dua dimensi sudut pandang dalam hubungan antar bangsa, yakni dalam sudut pandang ruang serta waktu. Ruang yang semakin terbatas dan juga waktu semakin berkurang dalam sebuah korelasi dan hubungan komunikasi dalam lingkup dunia. Globalisasi terjadi hampir di segala segi kehidupan misalnya saja dalam bidang ideologi politik, ekonomi, sosial budaya, pertahanan keamanan dan juga yang lainnya. Perkembangam teknologi informatika dan komunikasi dalam skala dunia merupakan sebuah aspek yang menjadi pendorong utama dalam terjadinya globalisasi. Pendidikan karakter bangsa Indonesia di era globalisasi saat ini sangat penting demi memperlihatkan karakter bangsa didalam kehidupan gobal. Sekarang ini, pertumbuhan teknologi yang terjadi begitu cepat membuat semua informasi dapat dengan mudah dan dalam berbagai bentuk dan kepentingan dapat dengan cepat tersebar luas ke seluruh antero dunia. Oleh sebab itulah tidak ada yang dapat terhindar dari kehadiran sebuah globalisasi.

Peran Globalisasi di Indonesia sudah tentu akan memberikan pengaruh terhadap nilai- nilai siemangat kebangsaan (nasionalisme) terhadap bangsa Indonesia. Dampak positif dari adanya globalisasi pada sebuah arti nasionalisme, ialah diantaranya sebagai berikut: 1.) Ditinjau dari politik secara global, sebuah pemerintahan yang diopersikan dengan cara yang terbuka, transparan dan juga demokratis. Sebab sebuah pemerintahan merupakan satu kesatuan dari sebuah negara, yang bila pemerintahan berjalan dengan cara yang jujur, bersih serta dinamis sudah dapat dipastikan akan 
membuat rakyat memberi tanggapan yang baik dan positif. Tanggapan yang positif dapat berwujudupaya menjaga keutuhan NKRI. 2). Ditinjau dari segi ekonomi secara global, pasar internasional yang kian hari kian terbuka lebar meningkatkan peluang dan juga kesempatan kerja yang dapat membantu meningkatkan pendapatan devisa negara. Dengan begitu pula akan dapat meubah serta meningkatkan taraf ekonomi bangsa yang turut serta mendukung kehidupan nasional dalam berbangsa dan bernegara.

Dengan adanya sebuah globalisasi sudah barang tentu memberikan sebuah pengaruh dalam kehidupan sebuah negara terutama Indonesia. Imbas dari hal tersebut mencakup dua hal mendasar yakni membawa imbas positif serta imbas yang negatif. Membangun karakter bangsa di era globalisasi mnjadi sebuah hal yang penting demi mengurangi dampak yang dapat merugikan bangsa dan negara secara keseluruhan. Dampak yang ditimbulkan dengan meliputi berbagai aspek kehidupan misalnya dalam aspek kehidupan politik, ideologi, sosial budaya dan ekonomi juga yang lainnya.

\section{Pemahaman Masyarakat Terhadap Pancasila}

Pancasila merupakan filsafat dan pandangan hidup Bangsa Indonesia yang digali dari bumi pertiwi, dan telah diyakini bahwa nilai-nilai yang terkandung di dalamnya berlaku dalam kehidupan berbangsa, bernegara, dan bermasyarakat. Pancasila sebagai landasan moral bangsa mengisyaratkan bahwa dalam mencapai cita-cita nasional harus menjadi pegangan agar tidak menyimpang dalam mencapai tujuan bangsa dalam mensejahterakan rakyat. Proses pembangunan tidak hanya mendatangkan kemakmuran, tetapi juga harus menjamin keadilan sosial bagi seluruh rakyat Indonesia. Seluruh masyarakat Indonesia harus ikut-serta terlibat dalam setiap proses pembangunan, sehingga masyarakat merasa memiliki dan menjaga setiap hasil pembangunan.

Pancasila sebagai suatu sistem filsafat pada hakikatnya menjadi pedoman atau dasar bagi bangsa dalam memandang manusia,masyarakat, bangsa dan negara tentang makna hidup serta sebagai dasar negara. Pancasila dihubungkan dengan fungsinya sebagai nilai-nilai kebenaran yang telah dipilih oleh para pendiri negara ini, dengan lima silanya merupakan satu rangkaian kesatuan yang tidak terpisahkan. Pancasila merupakan wadah yang cukup fleksibel, yang dapat mencakup paham-paham positif yang dianut oleh bangsa Indonesia, karena sila-sila dari Pancasila itu terdiri dari nilai-nilai serta norma-norma yang positif sesuai dengan pandangan hidup bangsa Indonesia ,dan nilai serta norma yang bertentangan akan ditolak oleh bangsa Indonesia.

Pancasila merupakan sumber dari segala sumber hukum yang nilai-nilainya menjiwai setiap aturan yang berlaku dalam tatanan kehidupan bangsa. Peranan Pancasila sebagai falsafah pandangan hidup bangsa pada hakikatnya merupakan cerminan nilai-nilai dasar Pancasila secara harmonis, serasi, selaras dan seimbang dengan semangat persatuan dan kesatuan. Pancasila memiliki kekuatan yang mengikat secara hukum pada seluruh tatanan kehidupan bermasyarakat, berbangsa dan bernegara serta Sebagai pandangan bangsa Indonesia yang berasal dari nilai-nilai sebagai suatu corak dari kehidupan social budaya yang luhur. Nilai-nilai luhur tersebut telah mengakar dalam kehidupan warga negara Indonesia menjadi suatu pegangan untuk mencapai suatu tujuan kehidupannya sebagai suatu pandangan hidup bangsa. Bangsa Indonesia perlu melakukan perubahan pola pikir dalam kehidupan berbangsa bernegara, terutama dalam penerarapan nilai Pancasila. Karena jika tidak dimulai dari sekarang, Pancasila pada akhirnya akan hilang dalam kehudupan masyarakat Indonesia. Yang mendesak perlu dilakukan adalah semua lapisan masyarakat mulai dari lingkungan keluarga, sekolah dan pemerintah kembali mencuatkan Pancasila sebagai pegangan dalam bertindak dalam kehidupan sehari-hari. dalam perjalanan hidup seseorang memahami nilai Pancasila, tentunya akan tercipta sebuah kehidupan harmonis dan saling menghormati.

Dalam kondisi apapun Pancasila tidak bisa abaikan, jika Pancasila ditinggalakan, tentunya menjadi sebuah kondisi kritis negara ini. Pemahaman masyarakat terhadap nilai-nilai Pancasila sejalan dengan berkembangnya pengaruh negatif globalisasi dan juga semakin menguatnya nilai-nilai adat 
istiadat yang secara langsung maupun tidak langsung telah menimbulkan ekses terjadinya sikap dan perilaku masyarakat yang menyimpang dari nilai-nilai Sila dalam Pancasila pada tiap sila-nya bila tidak segera diatasi berpotensi untuk dapat menggerus kesadaran bela negara masyarakat dan meruntuhkan bangunan persatuan dan kesatuan bangsa, sehingga potensi kehancuran Negara Kesatuan Republik Indonesia akan sangat besar ditengah derasnya persaingan dalam percaturan bangsa dan negara di dunia dalam upaya meningkatkan pemahaman masyarakat terhadap nilai-nilai Pancasila melalui berbagai upaya sebagai berikut :

Pertama, Pembinaan akhlak dan perilaku masyarakat. Upaya untuk memperbaiki akhlak serta perilaku masyarakat tidak cukup dilakukan melalui kegiatan-kegiatan formal seperti upacara bendera, menyanyikan lagu kebangsaan atau sekedar mengenalkan masa perjuangan dulu, tetapi harus lebih konkrit pada upaya untuk memberi perhatian yang lebih dalam meningkatkan kualitas hidup dalam segala bidang kehidupan. Langkah yang perlu dan harus dilakukan antara lain dimulai dengan mengurangi konflik dalam masyarakat melalui perubahan sikap, perilaku dan akhlak masyarakat dari perilaku negatif menjadi perilaku positif. Perbaikan perilaku dan akhlak negatif tersebut dilakukan melalui langkah-langkah yang saling berhubungan dengan langkah-langkah di bidang lain serta dilakukan oleh pemerintah sebagai pengelola negara maupun oleh masyarakat sebagai subyek utama pembangunan.

Kedua, Peningkatan perhatian masyarakat terhadap nilai-nilai Pancasila. Dalam menghalau dampak negatif berkembangnya berbagai ideologi negara lain termasuk kuatnya pengaruh ideologi leluhur ditengah-tengah masyarakat, maka perhatian masyarakat terhadap nilai-nilai Pancasila harus kembali dapat ditingkatkan melalui serangkaian upaya dan kegiatan.

\section{KESIMPULAN}

Di zaman yang seperti sekarang ini, penanaman makna serta nilai pancasila harus diterapkan dalam kehidupan sehari-hari. Agar keberadaannya tidak hanya dijadikan sebagai simbol semata. Karena generasi muda saat ini sudah mengenal adanya teknologi informasi dan komunikasi yang berkembang sangat pesat. Hal tersebut berdampak buruk karena generasi muda di era sekarang banyak yang mengikuti kebudayaan luar tanpa menyaring kebudayaan tersebut sesuai dengan kaidah pancasila. Dengan adanya Pemahaman pancasila yaitu agar generasi atau masyarakat umum tidak tercabut dari akar budayanya sendiri dan agar mereka memiliki pedoman atau kaidah penuntun dalam berpikir serta bertindak dalam kehidupan sehari-hari dengan berlandas makna serta nilai Pancasila.

Pancasila diharapkan dapat menjadi pedoman hidup bagi manusia, baik bermasyarakat, bernegara maupun berbangsa. Sehingga dalam berperilaku serta bersosialisasi antar sesama manusia, baik dalam kehidupan bermasyarakat, berbangsa dan bernegara harus dilandasi oleh Pancasila yang dijadikan landasan dalam berprilaku. Pancasila juga dijadikan pedoman berbagai kehidupan, baik itu yang berkaitan dengan sosial, budaya, ekonomi dan lainnya. Sehingga segala sesuatu yang dilakukan diharapkan tidak melenceng atau sesuai dari aturan yang telah ditetapkan sesuai dengan Pancasila. Generasi muda kurang memiliki nilai kesadaran, oleh sebab itu banyak yang bertindak tidak sesuai dengan kaidah pancasila. Untuk mengatasi hal tersebut, perlu adanya pendidikan pancasila dan memahami supaya generasi di era sekarang mampu menyaring kebudayaan luar yang tidak sesuai dengan kaidah pancasila.

\section{Daftar Pustaka}

Kaelan, H., 2013, Negara Kebangsaan Pancasila, Paradigma, Yogyakarta

Rahmat dkk. (2009). Pembelajaran PKn. Bandung: Laboratorium Pkn UPI 
Srijanti, A Rahman HI, Purwanto SK, 2013, Pendidikan Kewarganegaraan Untuk Mahasiswa, Penerbit: Graha Ilmu Jogyakarta.

Sunoto. (1985). Mengenal Filsafat Pancasila; Pendekatan Melalui Metafisika, Logika, Etika. Yogyakarta: PT. Hanindita

Yudi Latif, 2014, MATA AIR KETELADANAN Pancasila Dalam Perbuatan, Penerbit: Mizan Anggota IKAPI Jakarta.

2018, Wawasan Pancasila, Penerbit: Mizan Anggota IKAPI Jakarta. 